\title{
Total energy expenditure in adults aged 65 years and over measured using doubly-labelled water: international data availability and opportunities for data sharing
}

Judi Porter ${ }^{1,2^{*}}$ (D) Kay Nguo ${ }^{1}$, Simone Gibson ${ }^{1}$, Catherine E. Huggins ${ }^{1}$, Jorja Collins ${ }^{1}$, Nicole J. Kellow ${ }^{1}$ and Helen Truby ${ }^{\top}$

\begin{abstract}
Background: Increasing population lifespan necessitates a greater understanding of nutritional needs in older adults (65 year and over). A synthesis of total energy expenditure in the older population has not been undertaken and is needed to inform nutritional requirements. We aimed to establish the extent of the international evidence for total energy expenditure (TEE) using doubly-labelled water (DLW) in older adults (65 years and over), report challenges in obtaining primary data, and make recommendations for future data sharing.

Methods: Four databases were searched to identify eligible studies; original research of any study design where participant level TEE was measured using DLW in participants aged $\geq 65$ years. Once studies were identified for inclusion, authors were contacted where data were not publicly available.

Results: Screening was undertaken of 1223 records; the review of 317 full text papers excluded 170 records. Corresponding or first authors of 147 eligible studies were contacted electronically. Participant level data were publicly available or provided by authors for 45 publications (890 participants aged $\geq 65$ years, with 248 aged $\geq 80$ years). Sixty-seven percent of the DLW data in this population were unavailable due to authors unable to be contacted or declining to participate, or data being irretrievable.
\end{abstract}

Conclusions: The lack of data access limits the value of the original research and its contribution to nutrition science. Openly accessible DLW data available through publications or a new international data repository would facilitate greater integration of current research with previous findings and ensure evidence is available to support the needs of the ageing population.

Trial registration: The protocol was registered with the International Prospective Register of Systematic Reviews (PROSPERO), registration number CRD42016047549.

Keywords: Total energy expenditure, Energy requirement, Doubly-labelled water, Older adults, Data repository

\footnotetext{
* Correspondence: judi.porter@monash.edu

${ }^{1}$ Department of Nutrition, Dietetics \& Food, Monash University, Level 1, 264

Ferntree Gully Road, Notting Hill, VIC 3168, Australia

${ }^{2}$ Allied Health Clinical Research Office, Eastern Health, 5 Arnold Street, 3128

Box Hill, VIC, Australia
} 


\section{Background}

The challenges of the global ageing population have been well documented, including the social [1], economic and impacts on the health system $[2,3]$. The United Nations forecast highlights the progressive nature of this ageing, "the number of older persons has tripled over the last 50 years; it will more than triple again over the next 50 years" [4]. It is predicted that the proportion of individuals aged over 80 years will increase fourfold to reach $4.1 \%$ of the world population in 2050. This milestone age group can be referred to as the 'older elderly', and are projected to total almost 379 million by 2050 [5].

The changing demographic of our globally ageing population has implications for both nutrition science and practice application. This practice at the population, community and individual level should be informed by the evidence base to ensure outcomes are optimised and resources are used efficiently. Energy and nutrient requirements are fundamental concepts in nutrition science, however a synthesis of the evidence for total energy expenditure in the older population has not previously been undertaken. A greater understanding of the energy needs of the older population will facilitate evidence translation to inform clinical practice and food provision at individual and broader system levels.

Doubly-labelled water (DLW) is the gold standard technique for measuring total energy expenditure (TEE) in free-living individuals. The first application of the DLW method in humans was published in 1982 by Schoeller and Van Santen [6] but its cost and analytical complexity has meant it remains a research tool rather than a method utilised in clinical practice. The review of Black et al. [7] in 1996 synthesised published and some previously unpublished TEE data assessed using DLW of 574 free-living people from affluent societies within the 2-95 years range. Yet to be undertaken however is an analysis of the evidence in the older population. In the first stage of an analysis of the energy requirements of older adults ( 65 years and over), we aimed to establish the extent of the international evidence for TEE using DLW, report challenges in obtaining primary data, and make recommendations for future data sharing.

\section{Methods}

Data identification were undertaken using principles of a systematic review, hence we followed and reported against the Preferred Reporting Items for Systematic Reviews and Meta-Analyses (Additional file 1: PRISMA) guidelines [8]. Prior to commencement, the protocol was registered with the International Prospective Register of Systematic Reviews (PROSPERO: http://www.crd.york.ac. uk/PROSPERO), registration number CRD42016047549, specifying the rationale, purpose and methodology for the review. This report focuses on the first component of the registered protocol: identifying and describing the process and availability of TEE data obtained via the DLW method. Analysis of participant level data will be conducted and reported later.

\section{Inclusion and exclusion criteria}

Eligible studies included those with participants aged 65 years and above, and where the population was heterogeneous in age but participant-level data could be obtained for those aged $\geq 65$ years. This age is classified internationally as the age for ceasing paid employment [4].

The intervention or assessment method of interest was DLW. This technique [9] is recognised as the reference method for the measurement of TEE and has been used in many populations, medical diagnoses and age groups. It is non-invasive to participants, and has been recognised as a technology that is restricted due to the high cost of the stable oxygen isotope and the technical complexity associated with analysis [10]. The primary outcome was participant-level TEE. For the purposes of this review, DLW measurements were accepted as reported irrespective of the variability in laboratory techniques (e.g. two-point and multi-point methods, duration). Accuracy of the DLW method has previously been estimated at $\pm 5 \%$ [7]. Where TEE was measured longitudinally (e.g. in the case of intervention studies), only the baseline measure was included.

Studies where participant-level data were obtained, including validation/comparison studies (e.g. comparing DLW with accelerometer), cross sectional or interventional studies were eligible for inclusion. Reviews, conference proceedings, and editorials were excluded. See Table 1 for summary of inclusion criteria.

\section{Search terms and strategy}

The search strategy used a variety of subject headings and synonyms relevant to the research question and was developed with an experienced systematic review search librarian. Search terms focused on the intervention and outcome, with age not considered within the search strategy so as not to unnecessarily limit the final library. The literature search was undertaken in MEDLINE

Table 1 Inclusion criteria for the review of DLW studies in adults aged 65 years and above

\begin{tabular}{ll}
\hline Parameter & Description \\
\hline Population & Adults aged 65 and over \\
Intervention/exposure & Doubly-labelled water \\
Comparison & No comparator \\
Outcomes & Total energy expenditure \\
Study design & Full text papers of any study \\
& design where participant-level \\
& data were available \\
\hline
\end{tabular}


complete, EMBASE, CINAHL Plus, and Cochrane Central from database inception to July 2016, with no language or date restrictions applied. The search strategy for MEDLINE complete is described in Fig. 1, with similar approaches applied in other databases. The reference lists of relevant systematic reviews were also searched to identify any papers that may have been missed by the search strategy.

\section{Study selection}

Searches were exported to Endnote with duplicates manually removed. Three contributors screened titles and abstracts independently, and in duplicate, to identify studies meeting the inclusion criteria. Any disagreement was resolved by consensus. Full text review was then undertaken by two authors in duplicate to confirm eligibility of studies.

\section{Data collection and extraction}

Corresponding authors were contacted by email by a member of the review team. One follow-up email was sent approximately one month following the initial approach. The purpose of the correspondence was to determine whether their study met the age criteria, and whether they had access to the original data to contribute to this review. An exemption from ethics approval was obtained from the University Human Research Ethics Committee (Project number 8025) for contacting authors and for requesting the collection of these data. Studies where participant-level data were available (either from data extracted directly from published papers inclusion or provided by authors) formed the final library for this review.

Other data sought from authors (or obtained, where reported, in published papers), included resting metabolic rate, age, weight, height, reported/known illnesses, and ethnicity.

The nature of authorship, with different first or corresponding authors within research collaborations and moving institutions led to some groups being contacted on more than one occasion for data. Data from the same original data set were also analysed and presented in multiple publications on several occasions, further confounding the data search. Duplicate data were minimised by grouping studies from the same data set together, as well as referring to the methods section of the papers to identify potential duplicate reporting of TEE data.

A spreadsheet was developed for management of all eligible papers and included identification of the publication and authors, whether any author could be contacted electronically, whether a response was obtained (regarding age of participants, data availability and contribution of data to the review). A second data extraction spreadsheet listed data provided by individual authors/research teams and, data extracted directly from published papers, where reported. Accuracy of data entered into spreadsheets was independently reviewed by two authors.

\section{Quality assessment}

Quality assessment of individual studies will be reported with the publication of primary data.

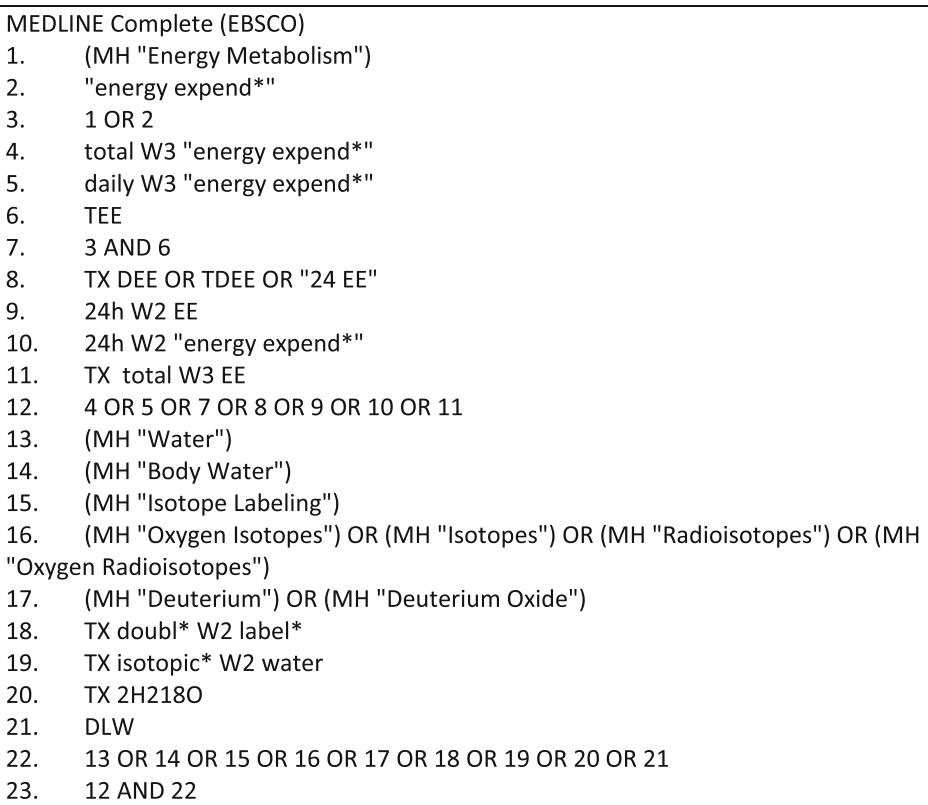

Fig. 1 Search Strategy for MEDLINE complete 


\section{Method of analysis}

The analysis presented in this paper is a descriptive synthesis of data availability, and participant-level data that has been obtained for further analysis. No primary analysis nor meta-analysis has been included here but will be reported later.

\section{Results}

Database searching yielded 1491 records, with a further five studies identified through other sources as indicated in Fig. 2. Following the removal of duplicates, 1223 records were screened. The review of 317 full text papers was undertaken that excluded a further 170 studies. Most papers excluded at this full text review were due to the wrong populations (e.g. age $<65$ years), the wrong outcome (e.g. energy expenditure not measured using DLW), or wrong study design (e.g. conference abstracts).

Authors of the remaining 147 studies were contacted by email to request provision of participant-level data for TEE and other variables. A summary of the outcomes of these communications is included in Table 2. Ten papers were able to be excluded as authors confirmed that study participants were all aged younger than 65 years, one additional paper included repeat data collection within a longitudinal study [11]. Three corresponding authors declined to participate, with 11 publications identified from these research groups. Therefore, a total of 102 papers of the 147 shortlisted papers were unavailable or excluded due to ineligible age/duplicate data.

Forty-five publications (28 studies) reporting on TEE in individuals aged $\geq 65$ years thus remain in the data set (Table 3). From these 45 published articles, participant level data were either publicly available or provided by authors for 890 participants aged 65 and over, with only 248 identified as aged 80 years and over. Authors of 30 publications to date generously contributed participant level data, whilst data from 15 publications were directly extracted from the published papers themselves. These data represent DLW studies conducted across all continents (with the exception of Antarctica) and in studies of ambulatory non-institutionalised people and those across a range of disease states. Overall, we have established that approximately $67 \%$ of the DLW data for the population of interest were unavailable.

\section{Discussion}

Our database search identified no reviews that had undertaken a systematic approach to identifying and collating the literature reporting TEE measured using DLW in an elderly population. Following the process of searching the literature, extracting data where reported,

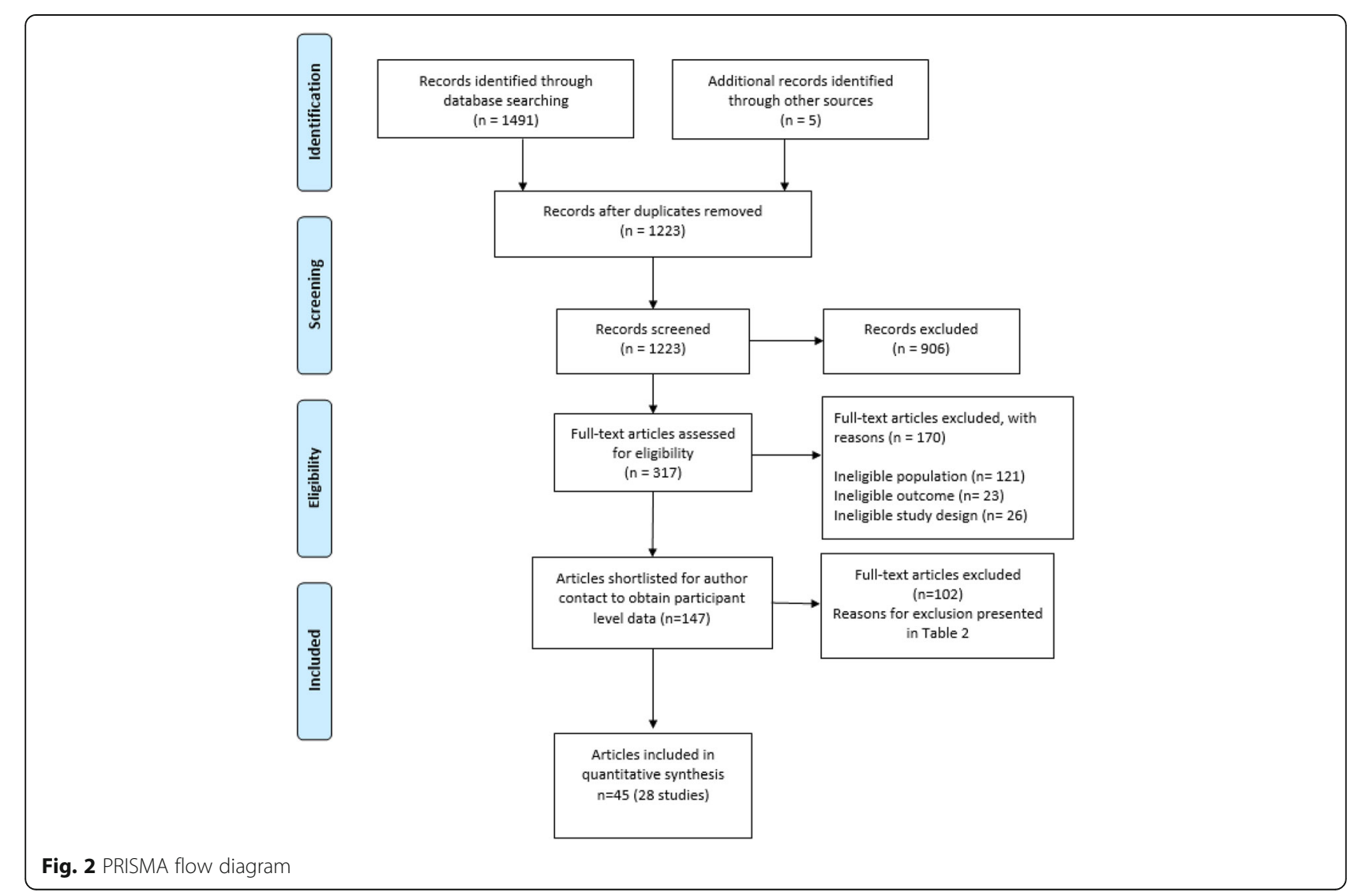


Table 2 DLW data availability in the systematic review of DLW in adults 65 years and over

\begin{tabular}{|c|c|}
\hline \multicolumn{2}{|c|}{$\begin{array}{l}\text { Total number of publications shortlisted for author contact to obtain } \\
\text { participant level data }(n=147)\end{array}$} \\
\hline Data availability & $\begin{array}{l}\text { Number of eligible } \\
\text { publications }\left(n=136^{\mathrm{a}} ; \%\right)\end{array}$ \\
\hline \multicolumn{2}{|l|}{ DATA THAT ARE UNAVAILABLE } \\
\hline Data no longer retrievable by authors & $34(25.0)$ \\
\hline $\begin{array}{l}\text { Corresponding or primary author } \\
\text { emailed twice with no response }\end{array}$ & $43(31.6)$ \\
\hline Authors declined to participate & 11 (3 groups of authors)(8.1) \\
\hline $\begin{array}{l}\text { Data available: have not yet been } \\
\text { provided by authors }\end{array}$ & 3 (1 group of authors) (2.2) \\
\hline $\begin{array}{l}\text { Total publications where data are } \\
\text { unavailable }\end{array}$ & $91(66.9)$ \\
\hline \multicolumn{2}{|l|}{ DATA THAT ARE AVAILABLE } \\
\hline $\begin{array}{l}\text { Data available: participant-level data } \\
\text { extracted directly from published paper }\end{array}$ & $15(11.0)$ \\
\hline $\begin{array}{l}\text { Data available: participant-level data } \\
\text { provided by authors }\end{array}$ & $30(22.1)$ \\
\hline $\begin{array}{l}\text { Individual publications where data are } \\
\text { available }\end{array}$ & $45(33.1)$ \\
\hline \multicolumn{2}{|l|}{ EXCLUDED DATA (ineligible) } \\
\hline $\begin{array}{l}\text { Total publications where no participants } \\
\text { were } 65 \text { years or over }\end{array}$ & 10 \\
\hline $\begin{array}{l}\text { Publications where data were recorded } \\
\text { longitudinally }\end{array}$ & 1 \\
\hline Total excluded data & 11 \\
\hline
\end{tabular}

${ }^{a} 147$ studies minus the 11 ineligible studies

${ }^{b}$ Where no contact was made with authors, it was assumed for calculating data availability that these studies met the age criteria for inclusion

or contacting research teams of published studies, we identified 890 participant-level data points of TEE from individuals aged 65 years and over. For those over 80 years of age only 248 data points are available, with 100 of those contributed by Frisard et al. in the USA [12] and 96 from the Health, Ageing and Body Composition Study (Health ABC study) [13-21].

The search for participant-level data was complicated by a range of factors, including the changing composition of research teams originally undertaking the studies and authorship and dual publications from an original data set. During the time since the commencement of the DLW technique (35 years ago), there have been many changes in the research workforce and changes in technology. At the time of the original DLW studies, computers and electronic data storage were in their infancy. Subsequently email addresses were unavailable for many corresponding authors in the published record, and author contact details were unable to be traced through usual search engines. Additionally, data were not retrievable by the authors in some instances.
An additional challenge was the time delay associated with obtaining original data from research groups. Some authors were required to submit ethics applications to their institutions to enable data sharing for this research. Other groups were unable to search for data until team members returned from periods of leave, or until other projects were complete. As such, data collection for this review did not run to the timeframe expected.

We have identified that approximately $67 \%$ of DLW data sets are missing or unavailable. Although our review was limited to a defined age group, we expect that similar access issues would apply across other age groups, and animals where DLW studies have been undertaken. This is problematic since the costs associated with studies using DLW have been lost. Also, the findings of these studies would enable a more comprehensive and therefore representative data set to be established.

Current technology is now available internationally for data sharing, openly accessible data, and international data repositories which would mitigate the challenges of identifying and collating TEE data and the missed opportunities for its utilisation. With the cost at almost \$AUD1000 per individual for isotopes alone to measure TEE using DLW, greater transparency in data reporting would support researchers internationally. Publication processes of some publishers require data access that support this ideal scenario. For example, the Public Library of Science (PLoS) have data reporting guidelines implemented whereby "all data and related metadata underlying the findings reported in a submitted manuscript should be deposited in an appropriate public repository, unless already provided as part of the submitted article" [22].

Alternatively, an international data repository should be considered. Data repositories and open access data have strengthened scientific research internationally over the past 20 years. Data sharing practices within the field of nutrition, and medicine more broadly are limited. Research data are not as available in repositories compared with other fields such as science and astronomy [23]. The Protein Data Bank is one example of an international collaboration for the deposition, processing and distribution of protein research. Founded in 1971, this repository stores three-dimensional structure data of biological macromolecules that have been determined under experimental conditions [24]. This repository captures and curates data using common practices and standards [24]. Although these data repositories are available at a specific project level, or sponsored from national bodies (National Research Infrastructure for Australia) [25], fewer are supported internationally.

Within healthcare, the Clinical Research Data Repository of the US National Institutes of Health has one of the largest publicly accessible research data repositories. 
Table 3 Details of participant-level data availability of studies of TEE using DLW in adults 65 years and over (total number of publications $=45$ )

\begin{tabular}{|c|c|c|c|}
\hline $\begin{array}{l}\text { Authors; year; country where study } \\
\text { undertaken }\end{array}$ & $\begin{array}{l}\text { Number of participant-level } \\
\text { data ( } 65 \text { years and over) }\end{array}$ & $\begin{array}{l}\text { Number of participant-level } \\
\text { data ( } 80 \text { years and over) }\end{array}$ & Population studied \\
\hline Prentice et al., 1989 [30]; England & 14 & 7 & Elderly mental health patients \\
\hline Goran \& Poehlman, 1992, 1992 [31, 32]; USA & 10 & 0 & Ambulatory non-institutionalised \\
\hline Pullicino et al., 1993 [33]; England & 1 & 0 & Intravenously fed patients \\
\hline Reilly et al., 1993 [34]; England & 10 & 0 & Ambulatory non-institutionalised \\
\hline Kashiwazaki et al., 1995 [35]; Bolivia & 2 & 0 & Bolivian Aymara \\
\hline Koea et al., 1995 [36]; New Zealand & 2 & 0 & $\begin{array}{l}\text { Ambulatory patients and patients } \\
\text { with sepsis }\end{array}$ \\
\hline Pannemans et al., 1995 [37]; Netherlands & 26 & 0 & Ambulatory non-institutionalised \\
\hline Rothenberg et al.; 2000,2002 [38, 39]; Sweden & 21 & 21 & Ambulatory non-institutionalised \\
\hline $\begin{array}{l}\text { Blanc et al., 2002, } 2004 \text { [13, 14]; } \\
\text { Middleton et al., } 2011 \text { [19]; } \\
\text { Manini et al., 2009, } 2009 \text { [17, 18]; } \\
\text { Shahar et al., 2009, } 2010 \text { [20, 21]; } \\
\text { Mackey et al., } 2011 \text { [16]; } \\
\text { Cooper et al., } 2013 \text { [15]; USA }\end{array}$ & 301 & 96 & Ambulatory non-institutionalised \\
\hline Rothenberg et al., 2003 [11]; Sweden & 11 & 0 & Ambulatory non-institutionalised \\
\hline Slinde et al., 2003 [40]; Sweden & 6 & 0 & $\begin{array}{l}\text { Chronic obstructive pulmonary } \\
\text { disease patients }\end{array}$ \\
\hline Hagfors et al.; 2005 [41]; Sweden & 3 & 0 & Rheumatoid arthritis patients \\
\hline $\begin{array}{l}\text { Arvidsson et al., } 2006 \text { [42] } \\
\text { AND Slinde et al., } 2006 \text { [43]; Sweden }\end{array}$ & 7 & 0 & $\begin{array}{l}\text { Chronic obstructive pulmonary } \\
\text { disease patients }\end{array}$ \\
\hline Frisard et al.; 2007 [12]; USA & 146 & 100 & Ambulatory non-institutionalised \\
\hline $\begin{array}{l}\text { Tooze et al., } 2007 \text { [44]; USA and } \\
\text { Bradley et al., } 2010 \text { [45]; USA }\end{array}$ & 65 & 0 & Ambulatory non-institutionalised \\
\hline Hertogh et al., 2008 [46]; Netherlands & 16 & 0 & Ambulatory non-institutionalised \\
\hline Moshfegh et al., 2008 [47]; USA & 48 & 0 & Ambulatory non-institutionalised \\
\hline Choquette et al.; 2009 [48]; Canada & 9 & 0 & Ambulatory non-institutionalised \\
\hline Yamada et al., 2009, 2013 [49, 50]; Japan & 30 & 8 & Ambulatory non-institutionalised \\
\hline Rothney et al., 2010 [51]; USA & 2 & 0 & Ambulatory non-institutionalised \\
\hline Colbert et al., 2011, 2014 [52, 53]; USA & 56 & 13 & Ambulatory non-institutionalised \\
\hline Ichihara et al., 2012 [54]; Japan & 6 & 0 & $\begin{array}{l}\text { Advanced amyotrophic lateral } \\
\text { sclerosis }\end{array}$ \\
\hline Pontzer et al., 2012, 2015 [55, 56]; Tanzania & 4 & 0 & $\begin{array}{l}\text { Hadza hunter-gatherers compared } \\
\text { with Western population }\end{array}$ \\
\hline Farooqi et al.; 2013, 2015, 2015 [57-59]; Sweden & 13 & 2 & $\begin{array}{l}\text { Chronic obstructive pulmonary } \\
\text { disease patients }\end{array}$ \\
\hline Calabro et al.;2015 [60]; USA & 22 & 0 & Ambulatory non-institutionalised \\
\hline Pfrimer et al., 2015 [61]; Brazil & 30 & 0 & Ambulatory non-institutionalised \\
\hline Rollo et al.; 2015 [62]; Australia & 4 & 0 & Type 2 diabetes \\
\hline Sridharan et al., 2016 [63]; England & 13 & 1 & Patients with chronic kidney disease \\
\hline TOTAL & 890 & 248 & - \\
\hline
\end{tabular}

Using a defined dictionary to unify terminologies from different data sources, this data repository includes in excess of 300 million rows of data [26]. Data retrieval can be made in identified form of an institutes' own research participants, and the de-identified data of all participants [26]. This is an example of the potential for collaboration offered by repositories in the sciences. The largest accessible data set of DLW data that we identified was of the participants of the Women's Health Institute study [27, 28] where data of 544 participants [27] and 450 participants [28] are stored. These data are available through an application process and engagement with a member of the research team. 
The next step from the establishment of a data repository is data mining, "to use existing data to help build the evidence base for effective nutritional care" [29]. The collaboration of previous and future researchers to contribute to a similar repository for results of studies of human energy expenditure is needed. Such a database once established would enable these valuable data to be stored and analysed by researchers into the future.

This research had several key strengths including a wide-ranging database search, and search terms across the intervention and outcomes of interest, whilst not scoping for age. This increased the likelihood of identifying all relevant studies into our title/abstract review. The absence of date and language restrictions are further strengths as the data set has not been compromised by either of these commonly applied limitations.

\section{Recommendations for future research}

Our planned analysis of the primary TEE data that we have obtained both from published sources and directly from authors will compare the accuracy of predictive equations commonly used in clinical practice against TEE determined through the DLW technique. This will be conducted for the broader elderly (65 years and over as we have scoped in this review) and for the older elderly (80 years and over) groups. As we have described, future research across the field of DLW would benefit from changes to process that ensure data are easily accessible. Data across clinical and other demographic subgroups could then be analysed to inform nutrition policy and practice at the population, community and individual patient/person level.

\section{Conclusion}

Our review of the peer-reviewed literature identified studies that report TEE measured by DLW in individuals aged 65 years and over. Participant-level data points for further analysis have been obtained from published data and author contact for 890 individuals. However, the majority of original data were irretrievable due to inability to contact authors, or due to changes in technology. The development of an international data repository would facilitate greater access for researchers to integrate current research with previous findings, thus ensuring that TEE data obtained using high cost methods are not lost to future generations.

\section{Additional file}

Additional file 1: PRISMA 2009 checklist. (DOC 63 kb)

\section{Acknowledgements}

Authors thank Ruth Lawrence from the Eastern Health Library service who completed the database searches. Two Monash University Nutrition \& Dietetic students, Elissa Elissa and Jana Duspara, assisted with the title and abstract review and were supported by University Vacation Research Scholarships. We also thank all the authors that were contacted in the completion of this review for their responses, and in many cases, for their contribution of participant-level data for further analysis, we appreciate their time and effort spent.

\section{Funding}

No specific funding was received to complete this review.

\section{Availability of data and materials}

The data set supporting the conclusions of this article is not presently available in a publicly accessible data repository for reasons described within the main text of the article.

\section{Authors' contributions}

All authors conceived and designed the research; JP and KN contributed equally to this work. JP, KN, CEH, SG, HT conducted data collection; JP, KN analysed data and wrote the paper; JP had primary responsibility for final content. All authors read and approved the final manuscript.

Ethics approval and consent to participate

An exemption from ethics approval was obtained from the University Human Research Ethics Committee (Project number 8025).

Consent for publication

All authors read and approved the final manuscript and give consent for its publication.

\section{Competing interests}

The authors declare that they have no competing interests.

\section{Publisher's Note}

Springer Nature remains neutral with regard to jurisdictional claims in published maps and institutional affiliations.

Received: 16 October 2017 Accepted: 19 March 2018

Published online: 26 March 2018

\section{References}

1. Tinker A. The social implications of an ageing population. Introduction Mech Ageing Dev. 2002;123(7):729-35.

2. Andrews GR. Promoting health and function in an ageing population. $\mathrm{Br}$ J Nutr. 2001;322(7288):728-9.

3. Kicklighter JR, Dorner B, Hunter AM, Kyle M, Pflugh Prescott M, Roberts S, Spear B, Hand RK, Byrne C. Visioning report 2017: a preferred path forward for the nutrition and dietetics profession. J Acad Nutr Diet. 2017;117(1):110-27.

4. United Nations, World Population Ageing: 1950-2050. Chapter III. Changing balance between age groups. New York: Department of Economic and Social Affairs; 2002 [cited 16 June 2017]. Available from: http://www.un.org/ esa/population/publications/worldageing19502050/pdf/81chapteriii.pdf.

5. United Nations, World Population Ageing: 1950-2050. Chapter IV: Demographic Profile of the Older Population. New York: Department of Economic and Social Affairs; 2002 [cited 16 June 2017]. Available from: http://www.un.org/esa/population/publications/worldageing19502050/ pdf/90chapteriv.pdf.

6. Schoeller DA, van Santen E. Measurement of energy expenditure in humans by doubly labeled water method. J Appl Physiol Respir Environ Exerc Physiol. 1982:53(4):955-9.

7. Black AE, Coward WA, Cole TJ, Prentice AM. Human energy expenditure in affluent societies: an analysis of 574 doubly-labelled water measurements. Eur J Clin Nutr. 1996;50(2):72-92.

8. Moher D, Liberati A, Tetzlaff J, Altman DG, Group P. Preferred reporting items for systematic reviews and meta-analyses: the PRISMA statement. $\mathrm{Br}$ Med J. 2009:339:b2535.

9. Schoeller DA, van Santen E, Peterson DW, Dietz W, Jaspan J, Klein PD. Total body water measurement in humans with 180 and $2 \mathrm{H}$ labeled water. Am J Clin Nutr. 1980;33(12):2686-93.

10. Westerterp KR. Doubly labelled water assessment of energy expenditure: principle, practice, and promise. Eur J Appl Physiol. 2017; 177(7):1277-85.

11. Rothenberg EMB, GI, Steen BC. Energy expenditure at age 73 and 78 - a five year follow-up. Acta Diabetol. 2003;40(SUPPL. 1):S134-S8. 
12. Frisard MIF, Jennifer M, Russell RD, King CM, DeLany JP, Wood RH, Ravussin E. Physical activity level and physical functionality in nonagenarians compared to individuals aged 60-74 years. J Gerontol A Biol Sci Med Sci. 2007;62(7):783-8.

13. Blanc SC, Amanda S, Trabulsi J, Harris T, Everhart JE, Bauer D, Schoeller DA Influence of delayed isotopic equilibration in urine on the accuracy of the (2) $\mathrm{H}(2)(18) O$ method in the elderly. J Appl Physiol. 2002;92(3):1036-44.

14. Blanc SS, Dale A, Bauer D, Danielson ME, Tylavsky F, Simonsick EM, Harris TB, Kritchevsky SB, Everhart JE. Energy requirements in the eighth decade of life. Am J Clin Nutr. 2004;79(2):303-10.

15. Cooper JAM, Todd M, Paton CM, Yamada Y, Everhart JE, Cummings S, Mackey DC, Newman AB, Glynn NW, Tylavsky F, Harris T, Schoeller DA Longitudinal change in energy expenditure and effects on energy requirements of the elderly. Nutr J. 2013;12:73.

16. Mackey DCM, Todd M, Schoeller DA, Koster A, Glynn NW, Goodpaster BH, Satterfield S, Newman AB, Harris TB, Cummings SR. Validation of an armband to measure daily energy expenditure in older adults. J Gerontol A Biol Sci Med Sci. 2011;66(10):1108-13.

17. Manini TME, James E, Anton SD, Schoeller DA, Cummings SR, Mackey DC, Delmonico MJ, Bauer DC, Simonsick EM, Colbert LH, Visser M, Tylavsky F, Newman AB, Harris TB. Activity energy expenditure and change in body composition in late life. Am J Clin Nutr. 2009;90(5):1336-42.

18. Manini TME, James E, Patel KV, Schoeller DA, Cummings S, Mackey DC, Bauer DC, Simonsick EM, Colbert LH, Visser M, Tylavsky F, Newman AB, Harris TB. Activity energy expenditure and mobility limitation in older adults: differential associations by sex. Am J Epidemiol. 2009;169(12): 1507-16.

19. Middleton LEM, Todd M, Simonsick EM, Harris TB, Barnes DE, Tylavsky F, Brach JS, Everhart JE, Yaffe K. Activity energy expenditure and incident cognitive impairment in older adults. Arch Intern Med. 2011;171(14):1251-7.

20. Shahar DR, Yu B, Houston DK, Kritchevsky SB, Lee JS, Rubin SM, Sellmeyer DE, Tylavsky FA, Harris TB. Dietary factors in relation to daily activity energy expenditure and mortality among older adults. J Nutr Health Aging. 2009; 13(5):414-20.

21. Shahar DR, Yu B, Houston DK, Kritchevsky SB, Newman AB, Sellmeyer DE, Tylavsky FA, Lee JS, Harris TB. Misreporting of energy intake in the elderly using doubly labeled water to measure total energy expenditure and weight change. J Am Coll Nutr. 2010;29(1):14-24.

22. Public Library of Science (PLOS) Medicine Submission Guidelines California: PLOS; [cited 16 June 2017]. Available from: http://journals.plos.org/ plosmedicine/s/submission-guidelines.

23. Borgman $\mathrm{CL}$. The conundrum of sharing research data. J Assoc Inf Sci Technol. 2012;63(6):1059-78

24. Berman H, Henrick K, Nakamura H, Markley JL. The worldwide protein data Bank (wwPDB): ensuring a single, uniform archive of PDB data. Nucleic Acids Res. 2006;35(suppl_1):D301-D3.

25. The Australian Research Data Infrastructure Strategy: National Research Infrastructure for Australia; 2014 [cited 201716 June]. Available from: https://docs.education.gov.au/documents/australian-research-datainfrastructure-strategy.

26. Cimino JJ, Ayres EJ. The clinical research data repository of the US Nationa Institutes of Health. Stud Health Technol Inform. 2010;160(Pt 2):1299.

27. Neuhouser ML, Tinker L, Shaw PA, Schoeller D, Bingham SA, Horn LV, Beresford SA, Caan B, Thomson C, Satterfield S. Use of recovery biomarkers to calibrate nutrient consumption self-reports in the Women's Health Initiative. Am J Epidemiol. 2008;167(10):1247-59.

28. Prentice RL, Mossavar-Rahmani Y, Huang Y, Van Horn L, Beresford SA, Caan B, Tinker L, Schoeller D, Bingham S, Eaton CB. Evaluation and comparison of food records, recalls, and frequencies for energy and protein assessment by using recovery biomarkers. Am J Epidemiol. 2011;174(5):591-603.

29. Batterham M, Neale E, Martin A, Tapsell L. Data mining: potential applications in research on nutrition and health. Nutr Diet. 2017;74(1):3-10

30. Prentice AM, Leavesley K, Murgatroyd PR, Coward WA, Schorah CJ, Bladon PT, Hullin RPI. Severe wasting in elderly mental patients caused by an excessive energy requirement? Age Ageing. 1989;18(3):158-67.

31. Goran MIP, Endurance ET. Training does not enhance total energy expenditure in healthy elderly persons. Am J Phys. 1992;263(5 Pt 1):E950-E7.

32. Goran MI, Poehlman ET. Total energy expenditure and energy requirements in healthy elderly persons. Metabolism. 1992;41(7):744-53.

33. Pullicino E, Coward A, Elia M. Total energy expenditure in intravenously fed patients measured by the doubly labeled water technique. Metabolism. 1993;42(1):58-64.
34. Reilly JJ, Lord A, Bunker W, Prentice AM, Coward WA, Thomas AJ, Briggs RS. Energy balance in healthy elderly women. Br J Nutr. 1993;69(1):21-7.

35. Kashiwazaki H, Dejima Y, Orias-Rivera J, Coward WA. Energy expenditure determined by the doubly labeled water method in Bolivian Aymara living in a high altitude agropastoral community. Am J Clin Nutr. 1995;62(5):901-10.

36. Koea JB, Wolfe RR, Shaw JH. Total energy expenditure during total parenteral nutrition: ambulatory patients at home versus patients with sepsis in surgical intensive care. Surgery. 1995;118(1):54-62.

37. Pannemans DL, Westerterp KR. Energy expenditure, physical activity and basal metabolic rate of elderly subjects. Br J Nutr. 1995;73(4):571-81.

38. Rothenberg EM. Resting, activity and total energy expenditure at age 91-96 compared to age 73. J Nutr Health Aging. 2002;6(3):177-8.

39. Rothenberg EM, Bosaeus IG, Westerterp KR, Steen BC. Resting energy expenditure, activity energy expenditure and total energy expenditure at age 91-96 years. Br J Nutr. 2000;84(3):319-24.

40. Slinde F, Ellegård L, Grönberg AM, Larsson S, Rossander-Hulthén L. Total energy expenditure in underweight patients with severe chronic obstructive pulmonary disease living at home. Clin Nutr. 2003;22(2):159-65.

41. Hagfors L, Westerterp K, Sköldstam L, Johansson G. Validity of reported energy expenditure and reported intake of energy, protein, sodium and potassium in rheumatoid arthritis patients in a dietary intervention study. Eur J Clin Nutr. 2005;59(2):238-45.

42. Arvidsson D, Slinde F, Nordenson A, Larsson S, Hulthén L. Validity of the ActiReg system in assessing energy requirement in chronic obstructive pulmonary disease patients. Clin Nutr. 2006;25(1):68-74.

43. Slinde F, Kvarnhult K, Grönberg AM, Nordenson A, Larsson S, Hulthén L. Energy expenditure in underweight chronic obstructive pulmonary disease patients before and during a physiotherapy programme. Eur J Clin Nutr. 2006:60(7):870-6.

44. Tooze JAS, Dale A, Subar AF, Kipnis V, Schatzkin A, Troiano RP. Total daily energy expenditure among middle-aged men and women: the OPEN study. Am J Clin Nutr. 2007:86(2):382-7.

45. Bradley DPJ, Lindsey A, Zhang Z, Subar AF, Troiano RP, Schatzkin A, Schoeller DA. Effect of smoking status on total energy expenditure. Nutr Metab. 2010;7:81.

46. Hertogh EMM, Evelyn M, Schouten EG, Peeters PH, Schuit AJ. Validity of the modified Baecke questionnaire: comparison with energy expenditure according to the doubly labeled water method. Int J Behav Nutr Phys Act. 2008;5:30.

47. Moshfegh AJR, Donna G, Baer DJ, Murayi T, Clemens JC, Rumpler WV, Paul DR, Sebastian RS, Kuczynski K, Ingwersen LA, Staples RC, Cleveland LE. The US Department of Agriculture Automated Multiple-Pass Method reduces bias in the collection of energy intakes. Am J Clin Nutr. 2008;88(2):324-32.

48. Choquette S, Chuin A, Lalancette DA, Brochu M, Dionne IJ. Predicting energy expenditure in elders with the metabolic cost of activities. Med Sci Sports Exerc. 2009;41(10):1915-20.

49. Yamada Y, Noriyasu R, Yokoyama K, Osaki T, Adachi T, Itoi A, Morimoto T, Oda S, Kimura M. Association between lifestyle and physical activity level in the elderly: a study using doubly labeled water and simplified physical activity record. Eur J Appl Physiol. 2013;113(10):2461-71.

50. Yamada Y, Yokoyama K, Noriyasu R, Osaki T, Adachi T, Itoi A, Naito Y, Morimoto T, Kimura M, Oda S. Light-intensity activities are important for estimating physical activity energy expenditure using uniaxial and triaxial accelerometers. Eur J Appl Physiol. 2009;105(1):141-52.

51. Rothney MPB, Robert J, Meade NN, Chen KY, Buchowski MS. Validation of the ActiGraph two-regression model for predicting energy expenditure. Med Sci Sports Exerc. 2010;42(9):1785-92.

52. Colbert LHM, Charles E, Havighurst TC, Kim K, Schoeller DA. Comparative validity of physical activity measures in older adults. Med Sci Sports Exerc 2011:43(5):867-76.

53. Colbert LHM, Charles E, Schoeller DA, Havighurst TC, Kim KM. Intensity of physical activity in the energy expenditure of older adults. J Aging Phys Act. 2014;22(4):571-7.

54. Ichihara N, Namba K, Ishikawa-Takata K, Sekine K, Takase M, Kamada Y, Fujii S. Energy requirement assessed by doubly-labeled water method in patients with advanced amyotrophic lateral sclerosis managed by tracheotomy positive pressure ventilation. Amyotrophic lateral sclerosis: official publication of the world federation of neurology research group on motor neuron. Diseases. 2012;13(6):544-9.

55. Pontzer HR, David A, Wood BM, Mabulla AZP, Racette SB, Marlowe FW. Hunter-gatherer energetics and human obesity. PLoS One. 2012;7(7):e40503-e. 
56. Pontzer H, Raichlen DA, Wood BM, Emery Thompson M, Racette SB, Mabulla AZ, Marlowe FW. Energy expenditure and activity among Hadza hunter-gatherers. Am J Hum Biol. 2015;27(5):628-37.

57. Faroogi N, Slinde F, Håqlin L, Sandström T. Validation of SenseWear Armband and ActiHeart monitors for assessments of daily energy expenditure in freeliving women with chronic obstructive pulmonary disease. Physiol Rep. 2013; 1(6):e00150-e.

58. Farooqi N, Slinde F, Carlsson M, Håglin L, Sandström T. Predicting energy requirement with pedometer-determined physical-activity level in women with chronic obstructive pulmonary disease. Int J Chron Obstruct Pulmon Dis. 2015;10:1129-37.

59. Faroogi N, Slinde F, Håglin L, Sandström T. Assessment of energy intake in women with chronic obstructive pulmonary disease: a doubly labeled water method study. J Nutr Health Aging. 2015;19(5):518-24.

60. Calabro MA, Kim Y, Franke WD, Stewart JM, Welk GJ. Objective and subjective measurement of energy expenditure in older adults: a doubly labeled water study. Eur J Clin Nutr. 2015;69(7):850-5.

61. Pfrimer K, Vilela M, Resende CM, Scagliusi FB, Marchini JS, Lima NK, Moriguti JC, Ferriolli E. Under-reporting of food intake and body fatness in independent older people: a doubly labelled water study. Age Ageing. 2015;44(1):103-8.

62. Rollo ME, Ash S, Lyons-Wall P, Russell AW. Evaluation of a mobile phone image-based dietary assessment method in adults with type 2 diabetes. Nutrients. 2015;7(6):4897-910.

63. Sridharan S, Wong J, Vilar E, Farrington K. Comparison of energy estimates in chronic kidney disease using doubly-labelled water. J Hum Nutr Diet. 2016;29(1):59-66.

\section{Submit your next manuscript to BioMed Central and we will help you at every step:}

- We accept pre-submission inquiries

- Our selector tool helps you to find the most relevant journal

- We provide round the clock customer support

- Convenient online submission

- Thorough peer review

- Inclusion in PubMed and all major indexing services

- Maximum visibility for your research

Submit your manuscript at www.biomedcentral.com/submit 